\title{
Physiotherapy- Correct, or Incorrect, Based on 'Wrong Principles of Treatment'. Example for Spine, Hip, Knee, Shank and Feet
}

\author{
Tomasz Karski* \\ Vincent Pol University, Poland \\ *Corresponding author: Tomasz Karski, Vincent Pol University, Poland

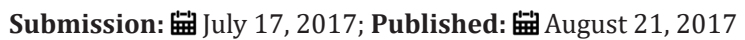

\begin{abstract}
The cases of spine, hips, knees, shank and feet problems are presented in the article. These patients before having contact with the author, had undergone a treatment in other medical centers. I could often stated that the previous therapy was not correct. The former therapy was based of wrong diagnosis connected very often with the weakness of muscles. After such diagnosis the recommended strengthening exercises never give good results. Only stretching exercises leading to the full and symmetrical movement of the joints and right loading during gait and standing is a proper method of treatment.
\end{abstract}

Keywords: Physiotherapy; Correct; Incorrect; Illnesses and deformations in movement apparatus

\section{Introduction}

On the all past years of my orthopedic activity (1961-2017) I could observe the various method of therapy- correct and unfortunately also incorrect. My teacher of orthopedics - grounder of orthopedics in Lublin District ( $7^{\text {th }}$ December 1954)- Professor Stanislaw Piatkowski had to spoken, it is important in orthopedics: $1 /$ proper diagnosis, 2 / simple conservative treatment, 3 / when such therapy is not possible- surgery, 4 / in all cases - prophylaxis.

In my orthopedic activity I had to treat all my patients according these rules (literature 1-37). I also had to observe that in Poland and in other countries (during my scholarship studies) the methods of therapy were far from this instructions. Below in article some examples.

\section{Material}

In the years 1961 till 2017 I observe the changeable character of illnesses and deformities, but also change able conception of therapy and often introducing improper methods of treatment. The cases observed were in ages from a few weeks to 90 years. There were 1345 cases with full documentation, with included X ray pictures from the years 2009-2016. The patients aged from a few months to 90 years, mostly were in the age of 7-18 and of 50-75 [1-5].

\section{Spine problems of children and youth}

This group of patients mostly had problems of the so-called idiopathic scoliosis (new term introduced in 1995). All the patients witch came to me-in previous therapies were treated by "strengthening exercises" it means this therapy were entirely improper. The extension exercises have never given good results. After such therapy the curves were bigger, the rip hump more extensive and the spine more stiff (literature) [6-10].

Only stretching exercises leading to full movement of hips, to proper position of pelvis and full movement of spine are correct. Here I inform - that also "standing 'at ease' on the left leg" is very important in therapy. All details according so-called idiopathic scoliosis and their treatment are presented in literature, in last years printed mostly in USA www.ortopedia.karski.lublin.pl

\section{Spine problems among adults}

The older patients suffered because of back pain. In my opinion the causes of "the syndrome of spinal pain" are:

A. Anterior tilt of pelvis and secondary hiperlordosis of lumbar spine making pressure to nerves roots,

B. Degenerative scoliosis (2nd group of scoliosis in new classification) with the similar influence,

C. Stiffness of spine (3rd group of scoliosis in new classification),

D. Spondylolisthesis and other congenital and acquisitioned malformations.

E. In Poland "back pain cases" are mostly diagnosed as "the prolapsed nucleus pulpous" and is recommended to the patients to undergo a surgery. In my opinion this diagnosis is proper only in $5 \%-10 \%$ of the cases. In $90 \%-95 \%$ of cases the pain is because of "pressure" in intervertebral spaces 
(foramina intervertebralis) on roots of nerves in concave side of scoliosis or because of "puling the roots" in convex side of the scoliosis. The only proper therapy is physiotherapy, and here the especially important role is placed in the extension therapy of spine, especially "chair extension", when patient lays on the back with flexions of the hips and the knees by 90 degree and with the trunk hanging $1 \mathrm{~cm}-2 \mathrm{~cm}$ over the bed. The author learned this method of therapy in Germany in 1969 (such method called in German "Perlsches Brett Behandlung"). Prof. K.F. Schlegel (I was the scholarship holder of DAAD in Professor's Schlegel Orthopedic Department in Essen in 1973) told me after years, during the Orthopedic Congress in Hungary, that "back pain" treated in Germany by surgery have never given good long lasting results and that only physiotherapy of the back pain is a proper method of treatment.

\section{Hips problems of children}

In prophylaxis of hip dysplasia it is very important to carry the child in the proper manner on parent's arms with the maximal abduction and flexion of the hips. The child should be facing the carrying person. Children should never be carried improperly, this means "facing to the street or to the shops". Such a wrong nursing is recommended by Polish wrongly educated rehabilitations doctors and physiotherapists. Such way of carrying the child is entirely wrong, because the hips are without full abduction, the potential dysplasia is not treated, the hand of mother or father is pressing very dangerously the abdomen, the child does not see the face of it's mother. The speech and psychological development of the child is delayed. These children very frequently develop a dysplasia or even a dislocation of the hips [16-20].

\section{Hips problems of adults}

The arthrosis can be in left hip as result of "not fully treated hip dysplasia" or in right hip as result of "Syndrome of Standing 'at ease' on the Right Leg". The prophylaxis of coxarthrosis should include recovering of full movements of hips joint - especially abduction, internal rotation and extension. Individual rehabilitation is very important, every day, over many years following these points:

a. Special position of standing - in abduction 20 or 30 degrees and in internal rotation,

b. Sitting - in internal rotation,

c. Walking - in small abduction,

d. Sleeping - in flexion and abduction of the hip joint (to this subject publication in Jacobs Journal of Physiotherapy and Exercise, 2016 / Texas / USA). In program of physiotherapy in my country it is spoken only about "necessity to strengthen the muscles". Such therapy never gives the positive results. On end of such improper therapy it is only - surgery - hip prosthesis [21-25].

\section{Knees problems among children}

The valgus deformity of children mostly develops because of improper sitting manner many months or many years - with legs placed on side of the body and in maximal internal rotation of the hips. The valgus deformity of knees can develop also among children with Minimal Brain Dysfunctions (MBD- publication in Czech Republic in 2017). Pediatrician, orthopedic surgeons and rehabilitation doctors should inform parents about necessity of sitting in proper position - it means in "butterfly position" (term taken from the karate) -feet together, knees apart, hips in maximal abduction [26-29].

\section{Knees problems of adults}

The adult patients can suffer because of arthrosis of knee or of patello - femoral joint. The following factors lead to the arthrosis:

a. Primary valgus deformity and after years instability of knee.

b. Varus deformity and next instability of joint.

c. Contracture (limited extension) of the knee.

d. Recurvation of knee in patients with symptoms of MBD (beginning of the deformity in childhood).

e. Arthrosis of patello - femoral joint, in result of various pathological influences (need special article). The patients were very commonly treated by extensive movement of knee - from full flexion to full extension. Such kinesiotherapy is incorrect. Proper exercise - there are only isometric exercises for m. quadriceps. The leg should be in permanent extension position of the knee regularly lifted up for $8-10$ second and placed down for $2-3$ second, plus extension / flexion movements of foot for better blood circulation.

\section{Shank problems among children and adults}

Mostly the problem is connected with varus deformity- and here can be distinguished three types of deformations. First type - Blount disease, second type-rickets, third types - deformity in kidneys illnesses. Till 70 years of XX century we treated the children with varus deformity only by surgery. After the ' 70 we found out, that the rejecting or reducing the "load" during standing or walking (see Heuter- Volkmann law), leads to the proper axis of shanks. Our method is simple, we recommend only - no standing and no walking during 2-3 months. The correction of axis of shank is coming spontaneously. Children aging from 1 to 2.5 years can be successfully treated with such a method (the first article about this subject was published in Germany in 1994). The varus deformity in adults needs surgery - corrective osteotomies.

\section{Feet problems of children}

Among almost $12 \%$ of children in Poland we observe the symptoms of MBD. These are:

a. Anterior tilt of pelvis with lumbar hiperlordosis,

b. Recurvation of knees and

c. Valgus, or plano - valgus deformity of feet. The cause of this feet deformations is: laxity of joints (changed collagen) and shortening of Achilles tendon and m. triceps surae because 
of sub-spasticity. Valgus of feet has the character of "the secondary deformation". The physiotherapy in Poland of such feet is mostly incorrect. The correct therapy is only stretching exercises for Achilles tendon and m. tricep sure, the best in warm water. Additionally are recommended - inserts for shoes and among $5 \%$ of children - surgery.

\section{Foot problems among adults}

There are four common problems:

a. Valgus deformity of feet if such deformity is persistent from childhood.

b. Hallux valgus.

c. Pain syndrome of anterior part of foot" caused by the limited plantar flexion of the toes (articles from the 19611990).

d. Ankle joint pathology-left ankle among drivers, right one among passengers - caused by permanent distortion during getting out from the (small) car (article publish in American Research Journal of Medicine and Surgery, June 2017). The treatment of all the deformations mentioned above need proper physiotherapy and prophylactics' managements.

There are:

Table 1

\begin{tabular}{|c|c|c|}
\hline $\begin{array}{c}\text { Diagnosis and } \\
\text { Therapy in } \\
\text { observation of } \\
\text { Author Among the } \\
\text { Patients Coming from } \\
\text { Others Centers }\end{array}$ & $\begin{array}{c}\text { Spine - Children } \\
\text { (Scoliosis) and Adults } \\
\text { (Back Pain) }\end{array}$ & $\begin{array}{c}\text { Hips - Children } \\
\text { (Dysplasia) and } \\
\text { Adults (Arthrosis) }\end{array}$ \\
\hline Corrects therapy in \% & $20 \%$ & $50 \%$ \\
\hline Incorrect therapy in \% & $80 \%$ & $50 \%$ \\
\hline
\end{tabular}

\section{Acknowledgement}

May thanks for correcting of English to Mrs. Honorata Menet.

\section{References}

1. Tomasz K (1985) Der Zehenflexionstest zur Erkennung Frühzeitiger Stadien von Funktionsstörungen und Deformitäten der Vorfusses. Beitr Orthop Traumat 32: 305-307.

2. Tomasz K (1987) Muskule Hüftabduktionskontrakturen bei älteren Kindern. Ursachen und Behandlung, Beitr. OrthopTraumatologie 34(9): 476-480.

3. Tomasz K Konera W, Malicki M (1990) Statische und jatrogene Knieckplattfusdeformitäten bei Kinder. Erklerung der Erscheinungen und Möglichkeiten der Therapie. Orthopedic Congress in Hungary, Szekesfehervar, Hungary.

4. Tomasz K (1990) Our Philosophy in the early and late treatment of congenital hip dysplasia. Annales Univ Marie-Skłodowska 1990, LublinPolonia Vol. XLV, 7 Sectio D-Medicina, pp. 43-48.

5. Tomasz K (1991) Frühestbehandlung des muskulären Schlefhalses durch Torsionslagerung. Orthopädische Praxix 11(27): 691- 695.

6. Tomasz K, Drabik Z, Jacek K (1994) Agbemey Osteotomien in der Behandlung von Kindern mit Crura vara (M. Blount). Orthop Praxis, Heft 9, pp. 582-585. a. For valgus deformity of feet - the proper therapy is only stretching exercises of Achilles and m. trices surae in childhood,

b. The prophylaxis of hallux valgus is the using of proper shoes, not too narrow in every period of life,

c. Forefoot pain syndrome" need plantar flexion exercises of toes, the best in warm water,

d. Prophylaxis of ankle joint pain - proper getting out from the car - on both feet, without rotation movement of the body.

\section{Discussion and Conclusion}

Author presents various methods of therapy used by Polish physiotherapists in deformations of movement apparatus treatment among the children and the youths, or in pain syndromes treatment among adults. The presented material - cover the patients treated earlier in other Medical Centers and by various physiotherapists or orthopedic surgeons - very often with improper methods (Table 1). Such incorrect therapy was used because of the insufficient education of the physiotherapists and orthopedic surgeons or because of "over education" of these specialists. We live now in the time when, "everybody can make everything, everywhere", even to treat on a improper way. it is give impulse to "wide discussion about medical problems" to find the proper methods of the diagnosis and the proper therapy.
Knees - Children

(Valgus Deformity) and Adults

(Instability of Knee and Pain)

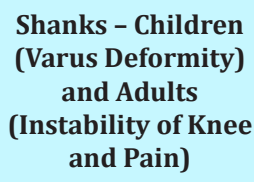

Shanks - Children

(Varus Deformity) and Adults (Instability of Knee and Pain)

Feet - Children

(Valgus Deformity) and Adults (Hallux Valgus, Pain Syndrome)

\begin{tabular}{|l|l|l|}
\hline $50 \%$ & $50 \%$ & $20 \%$ \\
\hline $50 \%$ & $50 \%$ & $80 \%$ \\
\hline
\end{tabular}

7. Tomasz K (2002) Etiology of the so-called "idiopathic scoliosis". Biomechanical explanation of spine deformity. Two groups of development of scoliosis. New rehabilitation treatment; possibility of prophylactics. Stud Health Technol Inform 91: 37-46.

8. Tomasz K (2004) Biomechanical factors in the etiology of idiopathic scoliosis: two etiopathological groups of spinal deformities. Ortop Traumatol Rehabil 6(6): 800-808.

9. Tomasz K (2006) Recent observations in the biomechanical etiology of so-called idiopathic scoliosis. New classification of spinal deformity-- ${ }^{\text {st }}$, $\mathrm{II}^{\text {nd }}$ and III ${ }^{\text {rd }}$ etiopathological groups. Stud Health Technol Inform 123: 473-482.

10. Jacek K, Kalakucki J, Jacek K (2006) Syndrome of contractures" (according to $\mathrm{Mau}$ ) with the abduction contracture of the right hip as causative factor for development of the so-called idiopathic scoliosis. Stud Health Technol Inform 123: 34-39.

11.Jacek K, Kałakucki J, Jacek K (2007) Relationship of "syndrome of contractures" in newborns with the development of the so-called idiopathic scoliosis. World J Pediatr 3(4): 254-259.

12. Tomasz K (2011) Biomechanical Etiology of the So-called Idiopathic Scoliosis (1995 - 2007) - Connection with Syndrome of ContracturesFundamental Information for Pediatricians in Program of Early Prophylactics. Journal of US-China Medical Science 8(5): 72-86. 
13. Karski T (2012) Present day explanation of the clinical signs in the biomechanical aetiology of the so-called idiopathic scoliosis (19952011). The relationship between the model of hips movement and the character of scoliosis; three groups and four types. The causative role of gait and standing at ease on the right leg. Stud Health Technol Inform 176: 133-138.

14. Karski T (2013) Biomechanical Etiology of the So-called Idiopathic Scoliosis (1995 - 2007). Three Groups and Four Types in the New Classification. Journal of Novel Physiotherapies p. 6.

15. Jacek K, Karski T (2013) So-Called Idiopathic Scoliosis: Diagnostic Tests; Examples of Children Incorrect Treated; New Therapy by Stretching Exercises and Results. Journal of Novel Physiotherapies, 3(2): 9.

16. Tomasz K (2014) Biomechanical Etiology of the So-called Idiopathic Scoliosis (1995-2007) - Connection with Syndrome of ContracturesFundamental Information for Pediatricians in Program of Early Prophylactics. Surgical Science 5: 33-38.

17. Tomasz K, Jacek K (2014) New Tests for Early Screening of the So Called Idiopathic Scoliosis. Global Journal of Medical Research 14(3): 8.

18. Tomasz K (2014) Biomechanical Aetiology of the So-Called Idiopathic Scoliosis. New Classification (1995 -2007) in Connection with "Model of Hips Movements. Global Journal of Medical Research 14(3): 1.

19. Karski T, Karski J (2104) Explanation of biomechanical aetiology of the so-called idiopathic scoliosis. Physiotherapy in treatment and in prophylaxis. Archive Physiotherapy and Global Research 18 (4): 7-11.

20. Tomasz K, Karski J (2015) Biomechanical etiology of the so-called Idiopathic Scoliosis (1995 - 2007). Causative role of gait and permanent standing at ease on the right leg. New classification. Principles of new therapy and causal prophylaxis. Canadian Open Medical Science \& Medicine Journal 1, (1): 1- 16.

21. Tomasz K (2015) Etiologia biomecanica de la conocida como Escoliosis Idiopatica. Nuevas clasioficationes (1995-2007): tres grupos y cuatro tipos de deformidades raquideas, 119-127 XXV Jordanas de Fisioterapia, 27-28 de Febrero, 2015. Actualizaciones en Fisioterapia. Ponencias
Escuela Universitaria de Fisioterapia de la ONCE, Univeridad Autonoma de Madrid, Spain.

22. Jacek K, Tomasz K (2015) Informacion sobre viejos metodos terapeuticos, presentacion de „nuevos ejercicios de stiramiento,, en el tratamiento y profilaxis de la escoliosis. Rsultados y wejemplos, XXV Jordanas de Fisioterapia, 27-28 de Febrero, 2015. Actualizaciones en Fisioterapia. Ponencias. Escuela Universitaria de Fisioterapia de la ONCE, Univeridad Autonoma de Madrid, pp. 134-142.

23.Tomasz K Jacek K (2015) Syndrome of Contractures and Deformities" according to Prof. Hans Mau as Primary Cause of Hip, Neck, Shank and Spine Deformities in Babies, Youth and Adults. American Research Journal of Medicine and Surgery 1(2).

24.Jacek K, Tomasz K (2016) Imperfect hips As a Problem at an Older Age. Early and Late Prophylactic Management before Arthrosis. Jacobs Journal of Physiotherapy and Exercises 2(1): 7.

25.Jacek K, Karski T (2016) Deformacje neuromięśniowe stóp, kolan, bioder, miednicy u dzieci. Wtórne zespoły bólowe u dorosłych. Przyczyny, zapobieganie i leczenie. (Deformations of the feet, knees, hips, pelvis in children with minimal brain dysfunction. Causes, prophylaxis and treatment in children and adults.). Neurol Prakt 16(1): 9-17

26. Tomasz K, Karski J (2016) Bóle krzyża - problem neurologiczno - ortopedyczny. Objawy, przyczyny, leczenie i profilaktyka. (Back pain - neurology - orthopedic problems. Clinic, causes, therapy and prophylaxis). Neurol Prakt 4(4): 9-16.

27. Karski J, Karski T, Pyrc J, Kulka M (2016) Deformations of the Feet, Knees, Hips, Pelvis in Children and Adults with Minimal Brain DysfunctionCauses Treatment Prophylaxis. Czech Republic Locomotor System 23(2): 20-31.

28. Karski J, Karski T, Karska K, Pyrc K (2017) Ankle Joint Pathology of Car Drivers and Passengers. Case report. American Research Journal of Medicine and Surgery 2: 1 .

29. www.ortopedia.karski.lublin.pl 